\title{
Diamond occurrence in kimberlites dependent on melting depths and rates of cooling of parental mantle magmas
}

\author{
Rass, I.T. ${ }^{1}$, Gerasimov, V.Yu. ${ }^{1}$, Laputina, I.P. ${ }^{1}$, and Ilupin, I.P. ${ }^{2}$
}

1. Institute of Geology of Ore Deposits, Petrography, Mineralogy and Geochemistry, Russian Academy of Sciences, 35 Staromonetny, Moscow 109017, Russia

2. Central Research Institute of Geological Prospecting for Base and Precious Metals (TsNIGRI), 129B Varshavskoye sh., Moscow 113545, Russia

Kimberlites are formed by mantle melting and formation of a water-carbonate-silicate fluid, supersaturated with volatiles, of low density and a high-migration ability. Diamond occurrence in kimberlites depends on the depth of magma formation and the speed at which the magma ascends to the surface and related fluid features (Perchuk and Vaganov, 1980).

A petrological indicator of melting depths of primary mantle magmas may be their Ca-content (Kravchenko et al., 1992), which reflects in their derivatives, more or less, from deep and shadow levels, respectively. The Ca-enriched kimberlites, the derivatives of primary magmas from greater melting depths are favorable for diamond occurrence, providing the absence of intermediate magmatic chambers in the hypabissal conditions, where melilite may crystallize. Thus, the occurrence of melilite in kimberlite is a guideline in the diamond-absence. To the contrary, the Ca-enriched kimberlites, monticelite-bearing, but without melilite, are diamond-bearing, as it is known for the Wesselton pipe. Recent experimental melting investigations on this kimberlite confirm the formation of its parental magma from the depths, greater then $250 \mathrm{~km}$ (Edgar and Charbonneau, 1993)

The above preliminary conclusions invite a statistical comparison of $\mathrm{Ca}$-rich and $\mathrm{Ca}$-poor, diamondrich, diamond-poor, and diamond-free kimberlites.

The rate of a kimberlite uplift is approximately proportional to the cooling rate of mantle xenoliths in its composition. We have studied the cooling history of the diamond-bearing kimberlite from the pipe Mir (Yakutiya, Russia). Detailed microprobe studies (Camebax-microbeem) of the minerals were undertaken paying special attention to the diffusion zones occurred between growth-zoned garnet and contacting biotite packed in intersecting cracks, and also the diffusion zones between the garnet and a clinopyroxene inclusion in it.

Thermometry of garnet-biotite equilibrium (Perchuk and Lavrent'eva, 1983) yields $\mathrm{T} \sim 730^{\circ} \mathrm{C}$ at $\mathrm{P} \sim 3 \mathrm{kbar}$. A diffusion zone is of about $4,5 \mu \mathrm{m}$. The model of nonequilibrium exchange reaction in a cooling petrological system (Lasaga, 1983; Gerasimov, 1983, 1992) is used to calculate the cooling rate. The cooling rate for this study, estimated by the diffusion model, is $2 \times 10^{4}{ }^{0} \mathrm{C} / \mathrm{Ma}$. As compared with the cooling rate of the diamond-bearing rocks from Kokchetav massif, Kazakhstan (Gerasimov and Dobzhinetskaya, 1996), it is less by half-magnitude.

\section{References}

Edgar, A.D., and Charbonneau, H.E., 1993, Melting experiments on a $\mathrm{SiO}_{2}$-poor, $\mathrm{CaO}$-rich aphanitic kimberlite from 5-10GPa and their bearing on sources of kimberlite magmas: Amer. Mineral., v.78, p. $132-142$

Gerasimov, V.Yu., 1992, Metamorphic thermal evolution and reversibility of mineral reactions, Moscow, Nauka, 129p. (in Russian)

Gerasimov, V.Yu., and Dobrzhinetskaya, L.F., 1996, Cooling history of the diamond-bearing rocks of the Kokchetav massif, Kazakhstan: 30 IGK, China, Abstracts, p.

Lasaga, A.C., 1983, Geospeedometry: an extension of geothermometry, in: Kinetics and Equilibrium in Geochemistry, Advances Physical Geochemistry, v.3, p.81-114 
Kravchenko, S.M., Rass, I.T., Ryabchikov, I.D., and Dikov, Yu.P., 1992, Ca-content increasing in mantle alkaline-ultrabasic melts by increasing of of melting depths: 29 IGC, Kyoto, Japan, 1992, Abstr., v. 2 of 3 , p.539

Perchuk, L.L., and Lavrent'eva, I.V., 1983, Experimental investigation of exchange equilibria in the system cordierite-garnet-biotite, in: Saxena, S.K., ed., Kinetics and Equilibrium in Mineral Reactions, Springer-Veriag, Berlin, p.199-239

Perchuk, L.L., and Vaganov, V.I., 1980, Petrochemical and thermodynamic evidence on the origin of kimberlites: Contrib. Mineral. Petrol., v.72, p.219-228 